\title{
CORRIGENDUM
}

\section{Reconstructing a Wartime Journey: The Vollard-Fabiani Collection, 1940-1949-CORRIGENDUM}

doi: $10.1017 /$ S0940739115000296

In Nancy Karrels' article "Reconstructing a Wartime Journey: The Vollard-Fabiani Collection, 1940-1949," the citation for Figure 1 incorrectly states that the dating of the Matisse piece is "c. 1942." The attribution of the piece should have been "Henri Matisse, Portrait of Martin Fabiani, January 1943."

The author regrets this error.

\section{BIBLIOGRAPHY}

Karrels, Nancy. 2015. "Reconstructing a Wartime Journey: The Vollard-Fabiani Collection, 1940-1949." International Journal of Cultural Property 22(4): 505-539. 